\title{
Density in mandibular trabeculae of beta thalassemia major patients at the age of $11-13$ years
}

\author{
Nisa Milati Biyantini*, Fahmi Oscandar*, Eriska Riyanti** \\ **Department of Dentomaxillofacial Radiology Faculty of Dentistry Universitas Padjadjaran \\ ${ }^{* *}$ Department of Pedodontics Faculty of Dentistry Universitas Padjadjaran
}

\begin{abstract}
Introduction: Density of mandible trabeculae is defined as density of trabeculae at posterior region of mandibulae. Systemic diseases which can affect bone density are osteoporosis and many types of anemia, including which has significant influence that is beta thalassemia major. The objective of this investigation was to obtain the data of density in mandible trabeculae of beta thalassemia major patients at the age of 11-13 years. Methods: The descriptive method was used in this study and the samples were selected using the total sampling technique. 15 periapical photos were obtained using the total sampling echnique. The periapical photos are administered using 3D-Doctor software. Data were analyzed using simple mean value formula. Results: Statistical count resulted in the minimum score of sample which was 98, 039 grayscale, the maximum score of sample which was 231, 34 grayscale, and the range score of sample which was 126.503 grayscale Conclusion: Density of mandible trabeculae of thalassemia beta major patients at the age of $11-13$ is 126.503 grayscale.
\end{abstract}

Keywords: Beta major thalassemia, density, mandibular trabeculae.

\section{INTRODUCTION}

According to Tipler (1991), density is the mass unit of a given volume. When associated with bone tissue, the density is defined as the amount of bone tissue in a given bone volume. ${ }^{1}$ Hildebolt, et al. (1992), suggest that the posterior mandibular density may represent the overall density of the mandible because the mandibular trabecular density may be considered as the density of the trabeculae in the posterior region of the mandible. ${ }^{2}$

Density is an important component of hard tissue because it can provide information about bone health and other related organs. The risk of fracture, cyst formation, and the spread of infection can be estimated from bone density. This density may be different in one individual to another because of systemic disease. Systemic diseases that can affect bone density include osteoporosis and various types of anemia, including significant effects are beta-major thalassemia. ${ }^{3}$

According to Spector and Josse $\mathrm{e}^{4,5}$ there is a significant reduction in bone density in patients with thalassemia beta major due to deterioration of flat bone microarchitecture. The dominant density reduction occurring in patients with thalassemia beta major is osteopenia. One of the flat bones of the human body is the mandible so that the mandible of the thalassemia beta major

Corresponding author: Fahmi Oscandar, Department of Dentomaxillofacial Radiology, Faculty of Dentistry Universitas Padjadjaran, Indonesia. Jalan Sekeloa Selatan I, Bandung, West Java, Indonesia, 40132; Phone: +6222-2504985/2532805 
patient is estimated to have a density reduction. The 3D-Doctor program software can be used to confirm these abnormalities by including the results of scanning of the periapical roentgen photo of a beta-major thalassemia patient. 3D-Doctor software is a program designed for measurement, processing, and modeling for MRI, CT, PET, science, microscopic and industrial imaging applications. The program also allows measurement with quantitative analysis. The vector-based 3D-Doctor equipment supports the ease of data handling, measurement and analysis. ${ }^{6}$ This study will primarily look at the density of the mandibular trabeculae which is estimated to be reduced from the large expansion of the bone marrow. The purpose of this study was to obtain data of mandibular trabecular density in patients with thalassemia beta major age 11-13 years.

\section{METHODS}

This research uses a descriptive method. The population in this study were secondary data of periapical photo of thalassemia beta major patient with age between eleven to thirteen years from medical record of DR General Hospital. Hasan Sadikin, Bandung. The photos used must meet the requirements of an accurate photo. Photos also should not experience color distortion because the software used works by detecting the white color radiopaque on foto. ${ }^{7}$

Sampling in total sampling from 60 secondary data subjects periapical photos of patients with thalassemia beta major age of 11-13 years. A total of 60 data subjects were selected to obtain 15 data used in the study. The sample taken as Region of Interest (ROI) is the bone between the two roots of the first permanent or second permanent molars on the mandible. The sample should have no lesions in periapical tissue and trabecular bone because it may affect bone density from the resorption mechanism on ROI. ${ }^{2}$

The variable in this study is the density of the mandibular trabeculae. The negligible variables in this study were gender, race, nutritional intake, and film density. Trabecular density in this study was measured using 3D-Doctor software. The first step is to scan a periapical photo with a scanner that has software for radiograph scan. Furthermore, the digital data is incorporated into

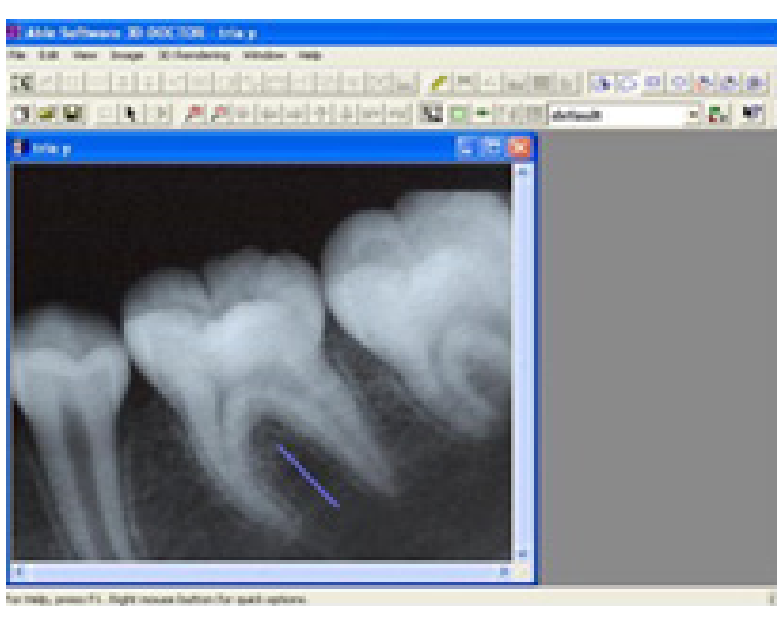

Figure 1. Monitor display at ROI marking

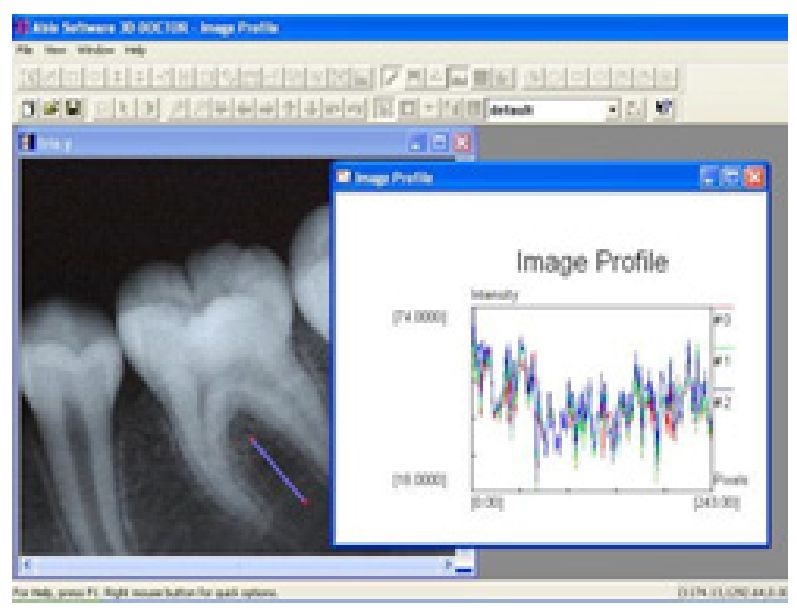

Figure 2. Display Monitor when Perform Intake Color Data Collection and Number of Pixels

3D-Doctor software. Then it's measured using the program's measurement and histogram. The last step is to record the color of intensity data and the number of pixels in the study table along with the name of patients with thalassemia beta major whose periapical photos are being measured.

Preliminary data obtained in the form of color intensity and the number of pixels and then processed into bone density data in grayscale units. The data were then analyzed to find the mean values of the samples, deviations, the highest values, the lowest values, and the range.

\section{RESULTS}

The study was conducted by measuring mandibular density on 15 periapical photos of thalassemia sufferers aged 11-13 years at Dental and Oral Hospital of Padjadjaran 
University, Bandung. Examples of table and figure presentation:

Table 4.1 shows the mean density of posterior mandibular trabeculae in patients with thalassemia beta major age of 11-13 years is 126,503 grayscale. We can calculate the average deviation from the data. This calculation is

Table 1 Trabecular Density Value of Mandibular ROI Thalassemia Beta Major Age 11-13 Years

\begin{tabular}{ll}
\hline Sample number & $\begin{array}{l}\text { Density Value of Thalassemia Beta Major } \\
\text { (grayscale) }\end{array}$ \\
\hline 1 & 100 \\
2 & 103.626943 \\
3 & 108.2474227 \\
4 & 197.6284585 \\
5 & 231.3432836 \\
6 & 204.0816327 \\
7 & 108.6956522 \\
8 & 101.1673152 \\
9 & 98.03921569 \\
10 & 100.6493506 \\
11 & 125 \\
12 & 102.7027027 \\
13 & 108.6956522 \\
14 & 103.7735849 \\
15 & 103.8961039 Rata-rata 126.5031545 \\
\hline
\end{tabular}

Table 2 Means and Standard Deviations of Trabecular Density Value of Thalassemia Beta Major Sufferers Age 11-13 Years

\begin{tabular}{lc}
\hline Sample Number & Deviation score \\
\hline 1 & 26.5031545 \\
2 & 22.8762115 \\
3 & 18.2557318 \\
4 & 18.2557318 \\
5 & 104.8401291 \\
6 & 77.5784782 \\
7 & 17.8075023 \\
8 & 25.3358393 \\
9 & 28.46393881 \\
10 & 25.8538039 \\
11 & 1.5031545 \\
12 & 23.8004518 \\
13 & 17.8075023 \\
14 & 22.7295696 \\
15 & 22.6070506 \\
\hline & average deviation \\
standard deviation & 33.80585481 \\
\hline
\end{tabular}

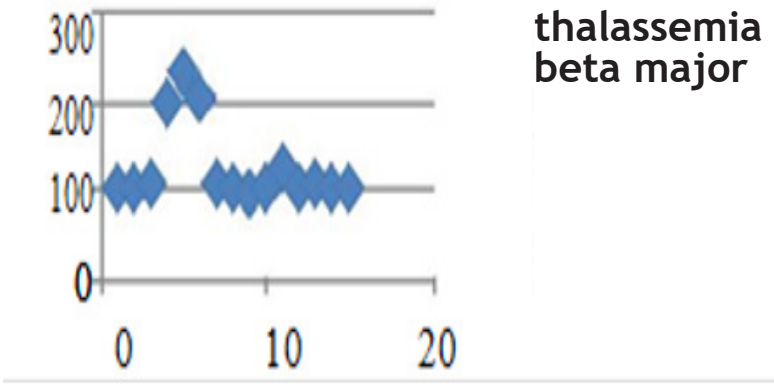

Graphics 1. Mandibular Trabecular Density Value Data for Thalassemia Beta Major Age 11-13 Years

useful to see if there is data that has a value difference too far compared to other data. The mean deviation and standard deviation from the research data can be seen in table 2 .

The results showed that the overall sample showed a value between 98,039 to 231.34 grayscale and had a range of 133,301 grayscale. The mean density of the overall sample was 126.5031545 grayscale rounded to 126,503 grayscale. The standard deviation value is 44,704 .

\section{DISCUSSION}

Based on the study results, it showed that patients with thalassemia beta major age of 11 . 13 years have an average mandibular density of $126.503 \pm 38,085$ grayscale. Bone density of thalassemia beta major patient has a low value according to this study. This is in accordance with the theory of Spector (1993) which states that flat bones of thalassemia beta major patients are more vulnerable due to excessive erythropoiesis to replace ruptured red blood cells. This erythropoiesis hyperactivity then causes trabecular deterioration resulting in reduced volume of hard tissue components. The flat bones found in the human body include the maxilla and the mandible. This process then leads to a low density of the mandibular trabeculae of patients with thalassemia beta major. ${ }^{4}$

Bone is a hard tissue that produces white color radiopaque on the film and healthy bones will produce a white color that contrasts with the film. The quality of this color will change if there 
are certain abnormalities in the bone. Osteopenia can provide a reduction in the quality of white color in the photo so as to provide a poor contrast. This can be seen in plain view, but measurement with the human eye alone is not accurate enough. Quantitative measurements were made for color quality observations that resulted in more accurate results. The reduction of the color intensity values digitally seen from the fading of white color which then affects the reduction of the obtained density value. ${ }^{3}$ This also proves the results of the research in graph 1 which shows the low density value of $80 \%$ of the sample.

From the data in table 2 it can be seen that the value in the sample of this research data has a large standard deviation value, which is 44.704 . This value is a great score considering the ideal standard deviation value should not exceed one sixth of the value of the range. The value of the range in this study is 133.301 . From this it can be said that the data obtained in this study is very heterogeneous data. This is supported by the distance value of each sample in table 2. The average deviation value is also a great value, which is 38,085 . From this value it can be concluded that there is a large error estimate for the mean value to describe the overall value of the sample. This may be due to the presence of negligible variables, namely sex, race, nutritional intake, and radiograph density. The sex and race variables are not variables that are considered to have much effect on the heterogeneity of the data. The reason for this is that data that have values with extreme distance values are not in a particular gender or race.

It can be seen in Table 2 that the average deviation value of $80 \%$ of data ranges between values from 1.503 to 28.46 but $20 \%$ of data gives a range of distance values between values 71.125 to 104.8401 . The span of averaged average deviation values on some of these data is worth noting. This indicates a possible lack of density measurement accuracy. Factors that are mainly suspected as the cause of this is the radiograph density which is a negligible variable in this study. This is in accordance with the opinion of Skodje, et al. (1998), said that the density of the radiograph may affect the diagnosis. ${ }^{8}$ The radiographic technical standard factor also has an important influence in addition to the ability of the diagnosis. The most easily manipulated technical standards are washing and exposure time. The washing of the film is the easiest to cause contrast of the mandibular contrast of children with thalassemia experiencing variation from 98,039 grayscale to 231,34 grayscale. Which it is suspected to have an effect on this is the different nutrient intake in each thalassemia sufferer. The effect of nutrient intake on mandibular density of thalassemia sufferers is in accordance with some research results that the nutritional deficiency factor often occurs in patients with thalassemia beta major. Patients with thalassemia beta major who are treated well will get a certain higher nutritional intake to compensate for the nutritional deficiencies that occur. Factors of malnutrition include the deficiency of vitamin C due to the rapid catabolism process and vitamin $\mathrm{E}$ deficiency due to hemolysis. Folic acid deficiency occurs due to reduced absorption, minimal dietary intake, and high vitamin demand due to rapid bone marrow expansion.9,10,11 Behrman and Vaughn (1998), suggesting that growth disorders may also be associated with chronic disease and factor nutrition. ${ }^{12}$ Moyers (1988), adding that socio-economic conditions are closely linked to nutritional factors. ${ }^{13}$ According to Herawan (2012), most thalassemia beta major patients are people with low socioeconomic conditions. This factor often affects the irregularity of blood transfusions and the ability of families to provide adequate nutrition for the sufferer.

Factors that can prevent the reduction of mandibular density of thalassemia beta major patient in the research subjects include the appropriate nutritional intake. According to Talwar (2007), bone density conditions can be increased by increasing the intake of calcium and vitamin D. ${ }^{14}$ This is supported by Ogston (2012) which suggests that the primary action of vitamin $D$ is to induce the absorption of calcium in digestion by stimulating the formation of calcium-binding protein in epithelial cells intestine. ${ }^{15}$ Vitamin $D$ also has a synergistic role with parathyroid hormone in stimulating osteoclast proliferation and bone resorption but vitamin $D$ has a much lower calcium-regulating effect than parathyroid hormone. Not all people with thalassemia beta major experience a family's economic status, nutritional deficiency, and a completely equal 
nutritional intake. This then causes the differences in the density values between the samples in table 1. This is also one of the things that causes the heterogeneity of data in table 2 .

The study results are consistent with Al-Jamal and Hazza'a (2006) research which states that thalassemia sufferers develop growth disorders, one of them in the teeth and jaws. ${ }^{16}$ This study is also in accordance with the research of Skodje et al. (1998), which states that radiograph density is an important factor influencing the accuracy of diagnosis. ${ }^{8}$ This study also provides incompatibility with previous research from Hildebolt (1992), which states that the accuracy value of digital radiometric research is $92 \% .^{2}$ It is said that because the distance value, the average deviation, or the standard deviation has a large value so that it can be said that the average value of density obtained is not a value that can represent the whole sample well.

The advantages of this research is the use of 3D-Doctor instrument that is easy to apply dentist anywhere, not necessarily in Hospital institutions through heavy equipment. This study also provides quantitative data on the state of trabecular density of patients with thalassemia beta major so that more objective assessment can be performed. The shortcomings of this study are the presence of average deviations and large standard deviations. According to Machfoedz (2007), the average deviation value indicates that the average value of the data is less reliable to represent the overall state of the data. ${ }^{17}$ The size of the standard deviation value indicates a lack of homogeneity of data so that the data is considered heterogeneous if the standard deviation value exceeds one sixth of the range.

\section{CONCLUSION}

Nandibular trabecular density value in patients with thalassemia beta major age of 11-13 years is 126.503 grayscale.

\section{REFERENCES}

1. Tipler, P. 1991. Fisika Untuk Sains dan Teknik Jilid 1. Edisi ketiga. Jakarta: Erlangga. 383 384.
2. Hildebolt, C.F, et al. 1992. Radiometric Classification of Alveolar Bone Health. Bethesda: National Research of Dental Institute vol.71 no.9. 1595-1596.

3. White and Pharoah. 2009. Oral Radiology: Principles and Interpretation. 6th Ed. Missouri: Mosby. 109-110, 175.

4. Spector WG. Pengantar Patologi Umum. Yogyakarta : Gadjah Mada University Press. 1993. p. 369-91.

5. Josse, R.G., et al. 2007. Low bone mineral density and fracture burden in postmenopausal women. Ottawa: CMAJ. 575-590

6. Able Software Corp. 2011. 3D-Doctor (software definition). Able Software Corp. available at: http://www.ablesw.com/ (diakses 11 Juni 2012)

7. Frommer, H., and J. Stabulas-Savage. 2005. Radiology For The Dental Professional. 8th ed. Missouri: Elsevier Mosby. 230-231.

8. Skodje, F, et al. 1998. The influence of radiographic exposure factors on the diagnosis of occlusal caries. Bergen: DMFR (27). 75-79.

9. Nathan, D.G and F.A. Oski. 1993. Haematology of Infancy and Childhood. 4th ed. Vol.I. Pensylvania: W.B. Saunders Company. 39.

10. Miller, D.R., et al. 1995. Blood Disease of Infancy and Childhood. 7th ed. Saint Louise: Mosby Year Book, Inc. 39.

11. Kosasih, E.N. 2001. Buku Ajar Ilmu Penyakit Dalam. Edisi 3. Jakarta ; Balai Penerbit Fakultas Kedokteran UI. 39.

12. Behrman and Vaughn. 1998. Ilmu Kesehatan Anak. Edisi 12. Jakarta : EGC. 36.

13. Moyers, R.E. 1988. Handbook of Orthodontics. $4^{\text {th }}$ ed. Chicago: Year Book Medical Publisher. 28.

14. Talwar, S., et al. 2007. Vitamin D Nutrition and Bone Mass in Adolescent Black Girls. Journal Of The Medical Association 2007;99(6):653-6.

15. Talwar, S., et al. 2007. Vitamin D Nutrition and Bone Mass in Adolescent Black Girls. J Med Association2007;99 (6):653-56.

16. Al-Jamal and Hazza'a. 2006. Dental development in subjects with thalassemia major. J Contemp Dent Pract. 4: 2.

17. Machfoedz, I. 2007. Statistika Deskriptif : Bidang Kesehatan, Keperawatan, dan Kebidanan (Biostatistik). Yogyakarta : Fitramaya. 83, 124-125. 